\title{
PRAKTIK PENERAPAN EXCLUSIONARY RULES DI INDONESIA
}

\author{
Adam Ilyas \\ Fakultas Hukum Universitas Pembangunan Nasional "Veteran” Jawa Timur \\ Jl. Rungkut Madya No.1, Gn. Anyar, Kec. Gn. Anyar, Surabaya, Jawa Timur 60294 \\ simplesemua@gmail.com
}

\begin{abstract}
Evidence is an important component in the case to decide a criminal case because with the evidence that will give rise to the judge's belief in the truth of a crime that has been committed by the defendant. Because of the importance of evidence tools so that it is also important the application of Exclusionary Rules. In this paper discussed about the application of Exclusionary Rules, problems in the application and solutions to the problem. As a result, in Indonesia has not implemented the principle of Exclusionary Rules because there are problems in the rules and law enforcement, thereby creating legal uncertainty, legal injustice, and even forming a corrupt culture of law enforcement in Indonesia so that a revision of the Criminal Code is required.
\end{abstract}

Key word: Evidence; Exclusionary Rules; Integrity of the Court; Human Rights.

\begin{abstract}
Abstrak
Alat bukti merupakan sebuah komponen penting dalam hal untuk memutuskan suatu perkara tindak pidana karena dengan alat bukti itulah yang akan menimbulkan keyakinan hakim atas kebenaran adanya suatu tindak pidana yang telah dilakukan oleh terdakwa. Karena pentingnya alat bukti sehingga penting pula adanya penerapan Exclusionary Rules. Dalam tulisan ini dibahas mengenai penerapan Exclusionary Rules, permasalahan dalam penerapan dan solusi atas permasalahan tersebut. Hasilnya, praktiknya di Indonesia belum secara mutlak menerapkan prinsip Exclusionary Rules ini karena permasalahan dari aturan dan penegak hukumnya, sehingga seringkali menimbulkan ketidakpastian hukum, ketidakadilan hukum, dan bahkan membentuk kultur korup penegakan hukum di Indonesia. Berdasarkan hal tersebut diperlukan adanya revisi terhadap Kitab Undang-Undang Hukum Acara Pidana terkait perkuatan penerapan prinsip Exclusionary Rules untuk memberikan perlindungan terhadap integritas pengadilan dan hak asasi manusia.
\end{abstract}

Kata Kunci: Alat bukti; Exclusionary Rules; Integritas Pengadilan; Hak Asasi Manusia.

\section{A. Pendahuluan}

Exclusionary Rules adalah istilah yang dikenal dalam hukum Amerika yang bermula dari doktrin "Fruit from the poisonous tree" yang memiliki makna bahwa alat bukti yang diperoleh dengan cara tidak sah tidak dapat digunakan (Pangaribuan, Mufti, \& Zikry, 2017). Prinsip Exclusionary Rules sebenarnya ada dan berlaku sejak tahun 1914 pada kasus weeks vs. united states akan tetapi penggunaan istilah Exclusionary Rules mulai dikenal ketika disebut pada kasus Mapp Vs Ohio pada tahun 1961. Berdasarkan perkara Mapp Vs Ohio, istilah Exclusionary Rules mengandung 4 (empat) pelanggaran, yakni: 1). Kesaksian yang didapat secara melawan hukum; 2). Kesaksian yang didapatkan dengan melanggar Amandemen Ke-5 dan Ke-6 yang berkaitan dengan prinsip Non-Self Incrimination; 3). Penggeledahan dan penyitaan yang bertentangan dengan Amandemen $\mathrm{Ke}-4$ yang berkaitan dengan 
perlindungan atas hak milik pribadi; dan 4). Bukti lainnya yang didapat secara melawan hukum yang penggunaannya dapat melanggar prinsip Due Process of Law (Atmasasmita, 1983). Terdapat dua pendekatan terkait legitimasi Exclusionary Rules ini, yakni yang pertama adalah pendekatan normatif, dan kedua adalah pendekatan faktual. Pendekatan normatif memfokuskan pada larangan penegak hukum untuk menggunakan alat bukti yang diperoleh dari cara melawan hukum, sedangkan pendekatan faktual memfokuskan pada pengertian bahwa mengenyampingkan bukti yang diperoleh secara ilegal dapat memberikan deterrence effect kepada penegak hukum (Zikry, 2014). Pemahaman ini berpegangan pada adagium "lebih baik membebaskan 1000 orang yang bersalah daripada menghukum 1 orang yang tidak bersalah", dipertegas dengan pernyataan Supreme Court yang menyatakan bahwa pemerintah (dalam hal ini aparat kepolisian) tidak diizinkan mendapat keuntungan dari kesalahannya sendiri (Oaks, 1970).

Jika melihat implementasi prinsip Exclusionary Rules di Jerman maka diketahui bahwa prinsip ini diterapkan secara khusus untuk statement yang diperoleh melalui perlakuan illegal seperti kekerasan dan perbuatan lain yang dilarang. Di Jerman sendiri praktik Exclusionary Rules bermula dari ketidakpercayaan terhadap polisi yang acapkali memperoleh dan menggunakan bukti secara melawan hukum.

Lain halnya dengan di Indonesia, justru keberlakuan Exclusionary Rules ini tidak serta merta membuat bukti tersebut tidak dapat diajukan, hanya "derajat" pembuktiannya saja yang menjadi berkurang (Atmasasmita, 1983). Oleh karena itu memang secara faktual di Indonesia masih menjadi perdebatan mengenai lebih mengutamakan kelancaran dalam melakukan pembuktian atau lebih mengutamakan perlindungan terhadap Hak Asasi Manusia.

Dalam tulisan ini akan dijelaskan mengenai permasalahan dalam praktik penerapan Exclusionary Rules di Indonesia. Permasalahan dalam tulisan ini sekaligus juga menunjukkan state of the art dan berikutnya akan menegaskan kebaruan dari pembahasan dalam tulisan ini. Walaupun dalam Kitab Undang-Undang Hukum Acara Pidana telah ada Frasa "alat bukti yang sah" yang setidak-tidaknya mengandung dua arti penting. Yakni yang pertama mengenai macamnya sebagaimana diatur dalam Pasal 184 Kitab Undang-Undang Hukum Acara pidana, dan yang kedua adalah cara memperoleh alat bukti tersebut. Tetapi permasalahannya bukti dan alat bukti merupakan dua hal yang berbeda, alat bukti yang sah dalam Kitab Undang-Undang Hukum Acara Pidana tidak termasuk barang bukti. Jadi sebenarnya secara mendasar yang menjadikan bukti masih dapat diajukan adalah karena permasalahan perbedaan pengertian antara alat bukti dan barang bukti, yang mana antara Criminal Procedure Law Amerika Serikat dan Kitab UndangUndang Hukum Acara Pidana Indonesia ternyata memiliki perbedaan pengertian mengenai hal tersebut.

Oleh karena itu, tulisan ini mencoba untuk menjelaskan apakah Exclusionary Rules sudah diterapkan dalam praktik penegakan hukum di Indonesia, dimana pengaturan mengenai Exclusionary Rules di Indonesia, permasalahan apa yang dihadapi dalam penerapan prinsip Exclusionary Rules serta hubungannya dengan perbedaan definisi alat bukti dengan barang bukti, dan yang terakhir adalah apa akibat dari tidak diterapkannya prinsip Exclusionary Rules secara sempurna di Indonesia.

\section{B. Pembahasan}

\section{Penerapan Exclusionary Rules di Indonesia}

Dalam sistem peradilan, keberadaan alat bukti sangat menentukan putusan hukum yang diambil oleh hakim. Bahwa dalam persidangan sebelum hakim menjatuhkan vonis, selalu didahului dengan pemeriksaan para saksi dan bukti-bukti lain yang dianggap dapat mendukung jalannya proses 
persidangan terutama dalam perkara pidana (Rusyadil, 2016). Dalam sistem hukum Indonesia alat bukti dan barang bukti merupakan dua hal yang berbeda. Terminologi barang bukti yang tidak ditemukan dalam Kitab Undang-Undang Hukum Acara Pidana menyebabkan timbul kekosongan hukum yang dapat mempersulit proses pemeriksaan dan pembuktian (Eato, 2017) atau seringkali tidak memberikan kepastian hukum bagi tersangka/terdakwa karena tidak ada aturan yang mengatur mengenai "barang bukti yang sah". Namun demikian, dapat didefinisikan bahwa barang bukti adalah benda bergerak atau tidak bergerak, berwujud atau tidak berwujud yang telah dilakukan penyitaan oleh penyidik untuk keperluan pemeriksaan dalam tingkat penyidikan, penuntutan, dan pemeriksaan di sidang pengadilan. Sedangkan alat bukti adalah segala sesuatu yang ada hubungannya dengan suatu perbuatan, dimana dengan alat-alat bukti tersebut dapat dipergunakan sebagai bahan pembuktian guna menimbulkan keyakinan hakim atas kebenaran adanya suatu tindak pidana yang telah dilakukan oleh terdakwa (Sasangka, Hari \& Rosita, 2003). Mengenai kekuatan pembuktian, barang bukti tidak memiliki kekuatan pembuktian, kecuali kemudian dapat diidentifikasi oleh alat bukti. Sebagai contoh, pistol yang digunakan untuk membunuh akan memiliki kekuatan pembuktian jika diakui oleh keterangan terdakwa. Jadi, barang bukti itu tidak dapat berdiri sendiri melainkan harus diberikan keterangan oleh saksi (Louis Pantow, 2018). Dapat dikatakan bahwa barang bukti merupakan bukti yang berbicara kepada dirinya sendiri, dan membuktikan alat bukti untuk membuatnya berbicara (Pangaribuan et al., 2017). Meskipun dalam Undang-Undang No. 8 Tahun 1981 tentang Hukum Acara Pidana tidak menyebut prinsip Exclusionary Rules secara eksplisit, namun dapat dimaknai dalam pasal 184 Kitab Undang-Undang Hukum Acara Pidana prinsip Exclusionary Rules ini tertuang, yakni yang menyatakan:

"Alat Bukti yang sah ialah: a. Keterangan saksi:

b. Surat;

c. Petunjuk;

d. Keterangan Terdakwa."

Adanya frasa "alat bukti yang sah" mengartikan makna bahwa setiap alat bukti sebagaimana diatur di pasal 184 Kitab Undang-Undang Hukum Acara Pidana adalah harus alat bukti yang sah baik cara memperolehnya maupun jenis alat buktinya. Dengan telah jelasnya aturan mengenai prinsip Exclusionary Rules di Indonesia seharusnya penegak hukum mengartikan frasa "alat bukti yang sah" berarti alat bukti yang tidak sah harus dikesampingkan. Oleh karena itu telah diketahui maksud dari pembuat Undang-Undang untuk memberikan perlindungan kepada tersangka atau terdakwa untuk tidak diadili dengan alat bukti yang tidak sah. Hal tersebut juga terdapat dalam putusan Mahkamah Agung No.1531 K/Pid.Sus/2010 yang menyatakan:

"Bahwa oleh karena itu, mengapa pembuat UU tidak membenarkan cara cara penangan seperti dalam perkara a quo, karena pembuat undang - undang sudah memikirkan dan mengantisipasi, bahwa pada suatu ketika akan terjadinya praktek rekayasa alat bukti/barang bukti untuk menjadikan orang menjadi tersangka. Apabila hal ini dibenarkan maka mudahnya orang jadi tersangka, sehingga polisi dapat memanfaatkannya sebagai alat pemerasan dsb.."

Namun, pada praktiknya masih banyak sekali penerapan "alat bukti yang sah" ini justru dikesampingkan dan dibenturkan dengan asas peradilan yang sederhana, cepat, dan biaya ringan sebagaimana diatur dalam Pasal 2 ayat (4) UU No. 48 Tahun 2009. Asas ini mengartikan bahwa peradilan cepat sangat diperlukan sebelum ada keputusan hakim (Eddy, 2017) dan hal tersebut seharusnya tidak boleh lepas dari perwujudan Hak Asasi Manusia. Dianggap sebagai pertentangan dengan asas tersebut karena apabila bukti/alat bukti yang diperoleh secara tidak sah tersebut tidak 
dipertimbangkan sama sekali maka akan menghambat proses peradilan. Sebagaimana dikatakan sebelumnya bahwa di Indonesia suatu bukti yang diperoleh dengan cara tidak sah tidak serta merta membuat bukti tersebut tidak dapat diajukan, hanya "derajat" pembuktiannya saja menjadi berkurang (Atmasasmita, 1983). Pendapat tersebut menunjukkan bahwa antara Dass Sollen dengan Das Sein tidak berjalan selaras atau bahkan bertentangan.

Untuk membuktikan apakah prinsip Exclusionary Rules secara praktik telah diterapkan atau belum, dapat dilihat dari hasil penelitian LBH Jakarta pada rentang 2007-2008 dengan responden 367 orang di wilayah Jabodetabek, menemukan bahwa $83,65 \%$ responden mengalami penyiksaan ketika diperiksa polisi (Gatot, 2008). Survey tersebut dilanjutkan pada tahun 2012 dan hasilnya menunjukkan bahwa angka penyiksaan tetap bahkan meningkat. Walaupun penyiksaan tersebut terjadinya di tingkat penyidikan, namun akan serta merta berpengaruh dengan alat bukti yang digunakan untuk memutus perkaranya. Bagaimana bisa hasil pemeriksaan polisi tersebut berpengaruh? Untuk menjawab pertanyaan tersebut, penulis uraikan seperti berikut: bahwa pengakuan seorang tersangka sebagai hasil dari praktik penyiksaan seharusnya tidak dapat dijadikan dasar pembuktian atau dasar dalam menentukan bersalah atau tidaknya seseorang sebagaimana asas Exclusionary Rules ini.

Sebenarnya Pasal 117 dan Pasal 52 Kitab Undang-Undang Hukum Acara Pidana telah mengatur mengenai keterangan saksi dan tersangka harus diberikan tanpa ada tekanan dari siapapun dan atau dalam bentuk apapun. Namun, pada praktiknya masih sering dijumpai tersangka yang sudah menjadi terdakwa mengakui apa yang disangkakan karena paksaan atau siksaan, mengalami kesulitan untuk membuktikan saat proses persidangan tentang adanya penyiksaan yang dialaminya karena sistem pembuktian yang dianut Indonesia yaitu negatief wettelijk beweijs theorie atau teori pembuktian menurut Undang-Undang secara negatif. Ketika seorang terdakwa mengatakan telah dipaksa mengaku karena disiksa, atau mengaku bahwa barang (yang membuat dia diadili) tersebut bukan miliknya, akan terganjal dengan sistem pembuktian di Indonesia yang menganut sistem pembuktian negatief wettelijk beweijs theorie atau teori pembuktian menurut Undang-Undang secara negatif atau juga karena berlakunya asas actori incumbit onus probandi, artinya siapa yang menuntut, dialah yang wajib membuktikan sehingga jaksalah yang memiliki kewajiban untuk membuktikan.

Terdakwa atau penasehat hukum hanya mempunyai hak untuk melumpuhkan pembuktian yang diajukan penuntut umum, sesuai dengan cara yang dibenarkan undangundang (Nugroho, 2017). Penyangkalan atas pembuktian penuntut umum, menurut penulis akan sulit dilakukan ketika mekanisme yang dilakukan ketika terdakwa mengaku disiksa adalah dengan menghadirkan saksi verbalisan. Dengan demikian terdakwa tidak dapat melakukan pembuktian, sehingga apabila terdakwa mengungkap terjadi suatu paksaan berupa kekerasan terdakwa tidak memiliki ruang untuk membuktikan dan sebaliknya yang membuktikan adalah jaksa dengan cara menghadirkan saksi verbalisan, pada akhirnya berujung pada kriminalisasi orang yang tidak bersalah. Berdasarkan Pasal 52 dan Pasal 117 Kitab Undang-Undang Hukum Acara Pidana dapat dikaitkan dengan prinsip Non Self Incrimination dari tersangka/terdakwa (hak dari tersangka untuk tidak mempersalahkan dirinya sendiri), sebagaimana tercermin secara tidak langsung dan implisit sifatnya pada Pasal 66 Kitab Undang-Undang Hukum Acara Pidana (Tersangka/terdakwa tidak dibebani kewajiban pembuktian) dan Pasal 189 Ayat (2) Kitab Undang-Undang Hukum Acara Pidana (Keterangan terdakwa hanya dapat dipergunakan bagi dirinya sendiri). Hak Asasi Manusia dalam hal ini tersangka ataupun terdakwa sebagaimana tercermin pada Pasal 52 dan 117 Kitab UndangUndang Hukum Acara Pidana, haruslah 
diartikan sedemikian rupa bahwa keterangan yang diberikan oleh tersangka itu bersumber pada free will (kehendak bebas) sehingga baik hakim maupun penyidik tidak diperkenankan untuk mencari keterangan yang tidak diberikan secara bebas. Tidak dipenuhinya persyaratan ini menimbulkan persoalan pembuktian yang diperoleh secara tidak sah (Sasmita, 2011). Dengan bukti uraian tersebut secara praktik berarti dapat dikatakan bahwa prinsip Exclusionary Rules belum berjalan dengan sebagaimana mestinya di Indonesia.

\section{Permasalahan Penerapan Prinsip Exclusionary Rules di Indonesia}

Dalam penerapannya Exclusionary Rules di Indonesia, masih terdapat permasalahan mendasar antara mendahulukan semangat membongkar kejahatan dengan perlindungan Hak Asasi Manusia. Sebagaimana penulis contohkan sebelumnya, salah satu permasalahannya adalah terkait perolehan keterangan tersangka di penyidikan yang ternyata diperoleh melalui kekerasan tidak serta merta dapat dikecualikan. Walaupun hasil pemeriksaan oleh pihak penyidik tidak lebih dari sekedar pedoman bagi hakim untuk menjalankan pemeriksaan (Mono, 2007) tetapi dalam alam praktik pengadilan, apabila terdakwa dan penasehat hukumnya mengungkap bahwa ada sebuah keterangan yang pengakuannya berdasar pada paksaan penyidik, maka hakim tidak serta merta akan mencabut pengakuan tersebut atau menganggap keterangan tersebut tidak ada melainkan akan terlebih dahulu menempuh mekanisme verbalisant, padahal berdasarkan asas Exclusionary Rules ini seorang terdakwa dapat mencegah penuntut umum untuk mengajukan bukti di pengadilan sebagai bukti yang dapat diterima karena diperoleh secara inkonstitusional. Prinsip Exclusionary Rules juga dapat menolak bukti probative dengan konsekuensi meniadakan tuntutan jaksa. Hal yang demikian tidak terjadi di sistem hukum Indonesia, justru akan terlebih dahulu menempuh mekanisme verbalisant yang menghadirkan saksi verbalisan, padahal biasanya setiap sistem hukum mengesampingkan alat bukti yang telah dipertimbangkan jika alat bukti tersebut tidak relevan atau tidak dapat dipercaya (Dressler, 2002).

Saksi verbalisan atau disebut juga dengan saksi penyidik adalah seorang penyidik yang bersaksi atas suatu perkara pidana karena terdakwa menyatakan bahwa Berita Acara Pemeriksaan telah dibuat di bawah tekanan atau paksaan (Rasyidi, 2017). Dalam proses beracara pidana mekanisme verbalisant dalam hal pencabutan keterangan adalah mekanisme yang sulit diterima akal sehat, karena penyidik yang melakukan penyidikan terhadap terdakwa akan dipanggil ke persidangan untuk didengar keterangannya terkait proses pemeriksaan perkara. Menjadi suatu hal yang mudah ditebak jawabannya, penyidik yang diperiksa tentu tidak akan mengakui ada paksaan atau kekerasan yang dilakukan kepada tersangka karena dengan mengakui hal tersebut bukan hanya dapat berimplikasi pada dimungkinkan dicabut keterangan tersebut, melainkan pada saat yang sama ia juga mengakui bahwa ada paksaan atau kekerasan yang ia lakukan terhadap terdakwa, sama saja halnya dengan penyidik tersebut mengakui bahwa ia telah melakukan tindak pidana.

Oleh karena itu sudah menjadi barang pasti penyidik yang didengar keterangan di hadapan persidangan tersebut tidak akan mengakui adanya paksaan dan kekerasan yang ia lakukan untuk mendapatkan pengakuan terdakwa. Akibatnya keterangan yang didapat penyidik terkait pengakuan tersangka dalam proses penyidikan akan tetap dijadikan acuan dalam persidangan. Selain itu, alasan logis lainnya terkait hubungan antara keterangan saat proses penyidikan dengan pemeriksaan perkara di pengadilan adalah dalam kegiatan penyidikan, penyidik mengumpulkan buktibukti untuk membuat terang tentang tindak pidana yang terjadi. Demikian pula dalam hal penyidik menentukan seseorang berstatus tersangka, setidak-tidaknya 
penyidik harus menguasai alat pembuktian yang disebut sebagai bukti permulaan. Jadi, meskipun kegiatan upaya pembuktian yang paling penting dan menentukan itu di muka sidang pengadilan, namun upaya pengumpulan sarana pembuktian itu sudah berperan dan berfungsi pada saat penyidikan (Rozi, 2019). Dengan begitu secara logika saat proses penyidikan sudah terdapat kesalahan, yakni dalam proses pengumpulan bukti itu dilakukan cara melawan hukum atau tidak secara sah, maka akan berpengaruh dengan pembuktian di pengadilan karena bukti adalah sesuatu untuk menyakinkan hakim tentang kebenaran suatu dalil, pendirian atau dakwaan (Haryanti, 2013).

KUHAP sebagai the rule dalam beracara, menganut secara ketat 3 (tiga) prinsip legalitas (Pribadi, 2018). Konsekuensi logis dari prinsip legalitas tersebut, maka dalam mencari kebenaran materiil, penegak hukum baik itu penyidik, penuntut umum, hakim, penasihat hukum harus menggunakan cara-cara yang diatur dalam ketentuan KUHAP (Rahim, Rahim, Rahim, Rahim, \& Rahim, 2020). Menyimpang dari KUHAP sebagai due process of law, maka hal tersebut merupakan exclusinary of rule, unlawfull legal evidence, maupun illegally acquired evidence, yang berujung pada dibebaskannya terdakwa (Hiariej, 2012). Namun, permasalahan di sini yang menjadikan prinsip Exclusionary Rules tidak berjalan sebagaimana mestinya di Indonesia adalah terletak pada Kitab Undang-Undang Hukum Acara Pidana itu sendiri. Walaupun telah diatur dalam Pasal 184 Kitab UndangUndang Hukum Acara Pidana terkait alat bukti yang sah, namun di dalam Kitab Undang-Undang Hukum Acara Pidana sama sekali tidak mengatur mengenai akibat hukum terhadap bukti-bukti yang diperoleh secara tidak sah. Selain itu tidak adanya pengaturan mengenai lembaga independen manakah yang berwenang untuk menentukan ketidakabsahan peroleh bukti yang tidak sah.
Dengan adanya kekosongan hukum ini justru lebih membawa peran Pengadilan dalam hal ini hakim untuk melakukan Rechtsvinding terhadap perbuatan-perbuatan yang tidak ditemukan aturannya dalam Kitab Undang-Undang Hukum Acara Pidana, hal ini menyebabkan ketidakpastian hukum. Apabila dikatakan bahwa praperadilan berfungsi sebagai sarana pengawasan terhadap Tindakan kepolisian dalam hal penyidikan maupun kejaksaan dalam hal penuntutan (Atmoko \& Bobby, 2018), menurut pendapat penulis praperadilan hanya bersifat pasif atau tidak aktif, artinya baru bekerja apabila ada inisiatif. Bisa dibayangkan jika yang menjadi tersangka adalah orang yang secara kemampuan ekonomi tidak memadai, akan menjadi tidak mungkin untuk membayar pengacara apalagi untuk mengajukan praperadilan, padahal belum tentu dia bersalah, bahkan berpotensi untuk dikriminalisasi secara melawan hukum dengan rekayasa-rekayasa bukti. Oleh karena tidak akseptabelnya mengenai prosedur yang melindungi hak tersangka atau orang lain yang mengalami kekerasan atau pemaksaan oleh aparat penegak hukum dalam proses pengumpulan bukti dalam kitab Undang-Undang Hukum Acara Pidana, membuat keleluasaan penegak hukum untuk melakukan tindakan yang semena-mena termasuk dalam hal mencari bukti. Dengan demikian praperadilan dipandang kurang efektif dalam mengawasi upaya paksa yang dilakukan aparat penegak hokum (Afandi, 2016). Berbeda jika dibandingkan di Amerika, Exclusionary Rules di United States Supreme Court, dengan jelas mengatur tentang penempatan akibat hukum bagi penyidik maupun tersangka terhadap perolehan alat bukti/bukti yang dilakukan dengan cara yang tidak sah.

Selain itu, perbedaan makna bukti dan alat bukti dalam Kitab Undang-Undang Hukum Acara pidana juga membuat bukti yang diperoleh secara melawan hukum tidak serta merta menggugurkan pemanfaatan barang bukti tersebut. Dalam Criminal 
Procedure Law Amerika Serikat yang disebut sebagai bukti adalah: 1). Real Evidence (Bukti sungguhan); 2). Documentary Evidence (Bukti documenter); 3). Testimonial Evidence (Bukti kesaksian); dan, 4). Judicial Evidence (Pengamatan hakim). Di Indonesia apa yang disebut sebagai real evidence adalah yang dikenal sebagai barang bukti. Perbedaannya adalah bahwa jika di Amerika Serikat real evidence merupakan bukti yang dipandang paling bernilai dibandingkan bukti lainnya, sementara di Indonesia bukti semacam ini tidak berkekuatan pembuktian. Alat bukti yang sah di Indonesia adalah sebagaimana yang ada di Pasal 184 Kitab UndangUndang Hukum Acara Pidana. Dari daftar alat-alat bukti yang sah, tampak bahwa barang bukti tidak disebutkan sebagai termasuk ke dalam salah satu alat bukti yang sah. Dengan kata lain, barang bukti bukanlah alat bukti (Lokas, 2015). Sehingga penerapan prinsip Exclusionary Rules di Indonesia hanya berlaku untuk alat bukti yang diatur dalam Pasal 184 Kitab UndangUndang Hukum Acara Pidana.

Selain itu, yang membedakan antara ketentuan alat bukti yang sah dengan Exclusionary Rules di Amerika Serikat adalah, berkaitan dengan jenis bukti itu sendiri. Sebagaimana telah penulis uraikan, alat bukti dan evidence di sistem hukum Amerika Serikat memiliki perbedaan mencolok tentang bagaimana memandang barang bukti. Prinsip Exclusionary Rules berguna untuk melindungi setiap orang dari apa yang disebut dengan illegal searches dan illegal seizure dengan doktrin fruits from poisonous tree, sementara itu di Indonesia, perolehan barang bukti secara melawan hukum tidak serta merta menggugurkan pemanfaatan barang bukti tersebut. Oleh karena itu kiranya perlu dilakukan revisi Kitab Undang-Undang Hukum Acara Pidana untuk memperbaiki kekurangan tersebut, yakni dengan memasukkan barang bukti ke dalam alat bukti yang sah dengan alasan bahwa dari sudut pandang kepentingan praktis sebenarnya jika barang bukti dipandang sebagai alat bukti akan lebih mempermudah pembuktian (Louis Pantow, 2018) dan juga akan memberikan kepastian hukum bagi tersangka/terdakwa.

Selain itu, penulis juga berpendapat bahwa perlu kiranya untuk menambahkan apa yang dinamakan hakim pemeriksa pendahuluan ke dalam Kitab UndangUndang Hukum Acara Pidana. Hakim pemeriksa pendahuluan adalah pejabat yang diberikan wewenang untuk menilai jalannya penyidikan dan penuntutan, serta berwenang pula memberikan izin bagi penyidik untuk melakukan upaya paksa. Jika kemudian hari Hakim pemeriksa pendahuluan tersebut menemukan dan menilai penyidik melawan hukum dalam perolehan bukti, maka Hakim pendahuluan dapat menolak bukti tersebut (Pangaribuan et al., 2017). Pengaturan tentang hakim pendahuluan ini adalah jawaban dari permasalahan penulis di atas baik mengenai mekanisme pra-peradilan yang pasif juga mengenai kepastian hukum bahwa bukti yang dihadirkan adalah wajib bukti yang diperoleh secara sah menurut hukum. Pengaturan ini penulis nilai sebagai pengaturan yang progresif dalam rangka reformasi hukum acara pidana sehingga tidak hanya memikirkan penanganan kasus yang cepat dan berbiaya murah tetapi juga berperspektif hak asasi manusia.

Contoh konkrit permasalahan penerapan prinsip Exclusionary Rules yang dihubungkan dengan proses penyidikan ada di kasus Dede Lutfi Alfiandi pembawa bendera saat adanya demo menolak Revisi Undang-Undang Komisi Pemberantasan Korupsi di depan Gedung Dewan Perwakilan Rakyat. Dalam persidangan muncul pengakuan yang mengejutkan masyarakat Indonesia, Lutfi mengatakan dalam persidangan bahwa ia mengalami proses kekerasan dalam bentuk disetrum agar mau mengakui bahwa ia melempar batu saat terjadinya demo. Bukti bahwa penerapan prinsip Exclusionary Rules belum berjalan dengan sebagaimana mestinya di kasus ini adalah bahwa Dede Lutfi Alfiandi tetap divonis bersalah dan dihukum 4 bulan penjara. Walaupun benar bahwa hakim itu 
bebas dalam memberikan penghargaan atau penilaian terhadap bahan bukti (Fauzan, 2015). Namun, kasus tersebut bertentangan dengan pernyataan dari Max M Hock yang menyatakan bahwa ada dua tipe bukti yang tidak dapat memperkuat suatu kasus, pertama, jika terjadi pertentangan antara satu dengan yang lain yang mana bukti-bukti tersebut berasal dari sumber yang berbeda dan tidak dirujuk. Kedua, bukti yang tidak dapat digunakan karena diperoleh secara ilegal yang disebut dengan tainted evidence (Houck, 2009).

Seharusnya jika melihat pendapat Max M Hock, Dede Lutfi Alfiandi diputus bebas, karena yang pertama, alasan saat ia ditangkap dengan sangkaan yang disangka oleh jaksa tidak relevan; kedua, saat proses penyidikan ia mengalami kekerasan sehingga ia terpaksa mengakui suatu perbuatan yang tidak ia lakukan. Dengan begitu dalam pemeriksaan memang hakim haruslah objektif dan mendengar kedua belah pihak yang berperkara. Karena sikap objektivitas hakim itulah, maka pembuktian dalam perkara pidana di Indonesia menganut pembuktian bebas. Artinya, hakim bebas untuk meyakini atau tidak meyakini sekalipun alat-alat bukti tersebut adalah alat bukti yang sah. Jika alat bukti yang diperoleh dengan cara sah saja hakim masih memiliki kewenangan untuk tidak meyakini, apalagi bahwa kemudian diketahui jika alat bukti tersebut tidak sah, maka hakim seharusnya tidak meyakininya. Perlu diingat bahwa tujuan hukum acara pidana adalah untuk mencapai kebenaran materiil, yaitu kebenaran yang selengkap-lengkapnya. Agar tujuan tersebut dapat tercapai, maka tindak pidana yang terjadi harus digali sampai ke akar-akarnya yang didasarkan pada alat-alat bukti yang sah yang diajukan dalam sidang pengadilan. Dengan tercapainya kebenaran material itu, maka terwujud juga nilai keadilan substantial dalam penegakan hukum pidana in concreto (Ramiyanto, 2017).

Oleh karena itu, terbukti uraian penulis terkait sejak dari proses penyidikan seharusnya prinsip Exclusionary Rules sudah harus diperhatikan, walaupun di dalam Pasal 184 Kitab Undang-Undang Hukum Acara pidana yang dikatakan alat bukti yang sah tidak termasuk keterangan tersangka, namun apabila dilihat dari uraian serta contoh konkrit tersebut, terlihat bahwa keterangan tersangka juga berpengaruh pada proses pengambilan putusan oleh Majelis Hakim karena pada dasarnya aspek pembuktian telah dimulai pada tahap penyelidikan hingga penjatuhan vonis oleh hakim (Ipakit, 2015).

\section{Akibat Belum Sempurnanya Penerapan Exclusionary Rules di Indonesia}

Sebagai sebuah prinsip, Exclusionary Rules tentu memberikan sebuah manfaat baik apabila diterapkan dan diatur sebagaimana mestinya. Manfaat baik tersebut bukan hanya kepada terdakwa, tetapi juga kepada institusi penegak hukum. Sebagaimana diketahui bahwa penerapan Exclusionary Rules erat kaitannya dengan integritas dari pengadilan. Begitu pula sebaliknya, apabila prinsip Exclusionary Rules ini tidak diterapkan dengan baik, maka akan membawa dampak buruk untuk institusi penegak hukum terlebih lagi untuk tersangka/terdakwa. Suatu akibat adanya penyimpangan dari prinsip Exclusionary Rules bagi tersangka/terdakwa adalah sama saja Hak Asasi Manusia tersangka/terdakwa telah dilanggar. Akibat tidak diterapkannya prinsip Exclusionary Rules dengan baik bagi institusi penegak hukum (dalam hal ini Pengadilan) adalah akan menjadikan pengadilan tidak memiliki integritas. Selain itu, akibat yang memiliki dampak paling besar dan paling berbahaya bagi kultur penegakan hukum Indonesia adalah terciptanya budaya korup. Budaya korup tersebut dapat terjadi karena terjadinya praktik rekayasa alat bukti/barang bukti untuk menjadikan seseorang menjadi tersangka, dengan rekayasa tersebut potensi untuk terjadinya pemerasan sangat besar. Selain untuk mencari keuntungan dengan memeras, sering kali terjadi rekayasa tersebut adalah pesanan dari orang-orang 
yang memiliki kepentingan untuk mentersangkakan orang lain. Penegak hukum (polisi dan jaksa) juga terkadang menggunakan rekayasa alat bukti/bukti ini untuk kepentingan jabatan dan masa depan karir kepangkatan atau dapat dikatakan demi memenuhi target yang diberikan oleh pimpinan. Apabila praktik ini terus menerus dibiarkan, akan menjadikan kultur hukum korup yang dapat merusak sistem hukum nasional, yang pada akhirnya tidak menegakkan hukum dengan mempertimbangkan asas keadilan, kepastian, dan kemanfaatan. Namun, justru mempertimbangkan kepentingankepentingan pribadi. Hal yang dimulainya dengan rekayasa, akan terus berlanjut sampai pada proses pemeriksaan di pengadilan bahkan tidak jarang diputus bersalah, walaupun orang tersebut sebenarnya tidak melakukan apa yang disangkakan. Dengan uraian tersebut menunjukkan betapa luasnya dampak tidak diterapkan dengan sebagaimana mestinya prinsip Exclusionary Rules. Bahkan dampak tersebut membentuk suatu kultur buruk yang akan merusak sistem hukum di Indonesia.

Untuk menyelesaikan seluruh persoalan yang telah disebutkan sebelumnya tentu bukan hal yang mudah. Tingkat perkembangan hukum di Indonesia sangat dipengaruhi tingkat peradaban atau kultural masyarakat dan kebijakan pengambil keputusan. Oleh karena itu, dibutuhkan sebuah perjuang besar dan waktu yang panjang secara nasional, tertata dan terlaksana untuk menumbuhkan penegakan hukum yang berkeadilan dan tidak melanggar hak asasi manusia serta tidak berpihak kepada kelompok ataupun orangorang yang memiliki kepentingan pribadi yang menggunakan kekuasaan negara untuk mempidanakan seseorang secara melawan hukum. Serta langkah penting yang harus segera dilakukan menurut penulis adalah untuk merevisi Kitab yang disebut-sebut sebagai karya agung bangsa Indonesia karena masih terdapat kekosongan hukum yang penulis nilai itu merupakan hal mendasar yang seharusnya diatur di dalam kitab Undang-Undang Hukum Acara Pidana.

\section{Simpulan}

Berdasarkan pembahasan sebelumnya, dapat disimpulkan bahwa prinsip Exclusionary Rules secara implisit telah diatur di Pasal 184 Kitab Undang-Undang Hukum Acara Pidana. Adanya frasa "alat bukti yang sah" tersebut menjadikan makna bahwa setiap bukti sebagaimana diatur di Pasal 184 Kitab Undang-Undang Hukum Acara Pidana adalah harus bukti yang sah baik cara memperolehnya maupun jenis alat bukti tersebut. Permasalahannya walaupun secara implisit telah diatur, Indonesia belum secara sempurna menerapkan prinsip Exclusionary Rules. Hal tersebut dibuktikan dengan masih terjadinya kekerasan yang dilakukan oleh penyidik kepada tersangka dengan tujuan agar tersangka mau mengakui sangkaan yang disangkakan kepadanya. Akibatnya, hal tersebut berimplikasi pada perolehan bukti yang tidak sah yang pada akhirnya digunakan untuk memutus tersangka tersebut saat proses di pengadilan. Permasalahan tersebut diperparah dengan tidak diaturnya di dalam Kitab UndangUndang Hukum Acara Pidana mengenai akibat hukum terhadap bukti-bukti yang diperoleh secara tidak sah dan mengenai lembaga independen manakah yang berwenang untuk menentukan ketidakabsahan peroleh bukti yang diperoleh dengan cara tidak sah tersebut. Selain itu, yang menjadikan permasalahan dalam penerapannya adalah adanya perbedaan antara ketentuan "alat bukti yang sah" dengan "Exclusionary Rules". Alat bukti di Indonesia dan evidence di sistem hukum Amerika Serikat memiliki perbedaan tentang bagaimana memandang barang bukti. Dengan perbedaan itu menjadikan apa yang disebut sebagai "bukti" dalam prinsip Exclusionary Rules belum diatur dalam Kitab Undang-Undang Hukum Acara Pidana. Yang sudah ada di dalam Pasal 184 Kitab Undang-Undang Hukum Acara pidana adalah hanya "alat bukti" yang berisi di antaranya keterangan saksi dan lain 
sebagainya bukan "barang bukti". Artinya "alat bukti yang sah" yang semula dipersamakan dengan Exclusionary Rules apabila diteliti lebih lanjut tidaklah sama karena dalam pasal 184 Kitab UndangUndang Hukum Acara Pidana yang disebut sebagai alat bukti yang sah tidak memuat barang bukti atau bukti, sedangkan yang ditekankan dari prinsip Exclusionary Rules adalah terkait dengan barang bukti sehingga dalam penerapannnya menimbulkan permasalahan di antaranya ketidakpastian hukum, ketidakadilan hukum, dan rusaknya kultur penegakan hukum yang pada akhirnya bermuara pada kultur korup.

Adapun saran yang dapat diusulkan kepada Dewan Perwakilan Rakyat dan Presiden sebagai pembentuk undang-undang adalah untuk melakukan revisi Kitab Undang-Undang Hukum Acara Pidana dengan tujuan untuk memperbaiki kekurangan tersebut, yakni memasukkan "barang bukti" ke dalam bagian dari "alat bukti yang sah" dan juga menambahkan apa yang dinamakan hakim pemeriksa pendahuluan ke dalam Kitab UndangUndang Hukum Acara Pidana agar tercapainya penegakan hukum yang berperspektif Hak Asasi Manusia dan sebagai bentuk penguatan penerapan prinsip Exclusionary Rules di Indonesia.

\section{DAFTAR PUSTAKA}

Afandi, F. (2016). Perbandingan Praktik Praperadilan Dan Pembentukan Hakim Pemeriksa Pendahuluan Dalam Peradilan Pidana Indonesia. Mimbar Hukum - Fakultas Hukum Universitas Gadjah Mada, 28(1), 93. https://doi.org/10.22146/jmh.15868

Atmasasmita, R. (1983). Bunga Rampai Hukum Acara Pidana. Bandung: Binacipta.

Atmoko, A. D., \& Bobby. (2018). Kedudukan Hukum Penyidik Terhadap Obyek Praperadilan. Jurnal Hukum Bisnis, 2(1).

Dressler, J. (2002). Encyclopedia of crime \& justice. In Choice Reviews Online (Vol. 39). https://doi.org/10.5860/choice.395554

Eato, Y. N. (2017). Keabsahan Alat Bukti Dan Barang Bukti Pada Perkara Pidana. Lex Crimen, 6(2).

Eddy, O. S. H. (2017). Hukum Acara Pidana. Tangerang Selatan: Universitas Terbuka.

Fauzan, H. (2015). Kaidah-kaidah Hukum Yurisprudensi , Norma -norma Baru Dalam Hukum Kasus. Jakarta: Kencana.

Gatot. (2008). Mengungkap Kejahatan Dengan Kejahatan;Survey Penyiksaan di Tingkat Kepolisian Wilayah Jakarta Tahun 2008. Jakarta.

Haryanti, D. (2013). Peranan Visum Et Refertum Sebagai Salah Satu Alat Bukti di Persidangan dalam Tindak Pidana Perkosaan. Jurnal Constitutum, 13(1), 603.

Hiariej, E. O. . (2012). Teori \& Hukum Pembuktian. Jakarta: Penerbit Erlangga.

Houck, M. (2009). Essentials of Foresic Science: Trace Evidence. New York: An Imprint of Infobase Publishing.

Ipakit, R. (2015). Urgensi Pembuktian Alat Bukti Dalam Praktek Peradilan Pidana. Lex Crimen, IV(2).

Lokas, R. (2015). Barang Bukti Dan Alat Bukti Dalam Kitab Undang-Undang Hukum Acara Pidana. Lex et Societatis, III $(9)$.

Louis Pantow, F. (2018). Hubungan Alat Bukti Dan Barang Bukti Dalam Sistem Kitab Undang-Undang Hukum Acara Pidana. Lex Crimen, 7(4).

Mono, H. (2007). Praktik Berpekara Pidana. Malang: Bayu Media.

Nugroho, B. (2017). Peranan Alat Bukti Dalam Perkara Pidana Dalam Putusan Hakim Menurut Kuhap. Yuridika, 32(1), 17. 
https://doi.org/10.20473/ydk.v32i1.478

0

Oaks, D. H. (1970). Studying the Exclusionary Rule in Search and Seizure. The University of Chicago Law Review, 37(4), 665. https://doi.org/10.2307/1598840

Pangaribuan, A. M. ., Mufti, A., \& Zikry, I. (2017). Pengantar Hukum Acara Pidana Di Indonesia. Rajawali Pers.

Pribadi, I. (2018). Legalitas Alat Bukti Elektronik Dalam Sistem Peradilan Pidana. Jurnal Lex Renaissance, 3(1). https://doi.org/10.20885/jlr.vol3.iss1.art 4

Rahim, M. I. F., Rahim, S. A. P., Rahim, M. A. H. A., Rahim, A. R., \& Rahim, A. (2020). Penyitaan Barang Bukti Tindak Pidana pada Tingkat Pemeriksaan Persidangan. Pleno Jure, 9(1), 47-57. https://doi.org/10.37541/plenojure.v9i1. 389

Ramiyanto, N. (2017). Bukti Elektronik Sebagai Alat Bukti Yang Sah Dalam Hukum Acara Pidana / Electronic Evidence As an Admissible Evidence in Criminal Law. Jurnal Hukum Dan Peradilan, 6(3), 463. https://doi.org/10.25216/jhp.6.3.2017.4 63-486

Rasyidi, A. F. (2017). Legalitas Penyidik
Sebagai Saksi Dalam Pemeriksaan Persidangan Tindak Pidana Narkotika (Analisis Pertimbangan Hakim Dalam Putusan Mahkamah Agung Nomor: 454 K/Pid.Sus/2011, 1531 K/Pid.Sus/2010, Dan 2588 K/Pid.Sus/2010). Jurnal Penelitian Hukum De Jure, 16(3), 353. https://doi.org/10.30641/dejure.2016.v1 6.353-369

Rozi, F. (2019). Sistem Pembuktian Dalam Proses Persidangan Pada Perkara Tindak Pidana. Jurnal Yuridis Unaja, 1(2), 19-33. https://doi.org/10.35141/jyu.v1i2.486

Rusyadil, I. (2016). Kekuatan alat bukti dalam persidangan perkara pidana. Jurnal Hukum PRIORIS, 5(2), 128-134.

Sasangka, Hari \& Rosita, L. (2003). Hukum Pembuktian Dalam Perkara Pidana. Bandung: Mandar Maju.

Sasmita, R. (2011). PENERAPAN ATAS PRADUGA TAK BERSALAH DALAM PRAKTEK PENANGANAN TINDAK PIDANA PENCURIAN (Studi Kasus Di Kota Mataram). Law Reform, 7(1), 50. https://doi.org/10.14710/lr.v7i1.12501

Zikry, I. (2014). Mengenal "Exclusionary Rules." Retrieved June 21, 2020, from LBH Jakarta website: https://www.bantuanhukum.or.id/web/ mengenal-exclusionary-rules/ 